\title{
Potential drug-drug interactions among pneumonia patients: do these matter in clinical perspectives?
}

\author{
Sidra Noor, Mohammad Ismail ${ }^{*}$ and Zahid Ali
}

\begin{abstract}
Background: Pneumonia patients are usually hospitalized due to severe nature of the disease or for the management of comorbid illnesses or associated symptoms. Such patients are prescribed with multiple medications which increase the likelihood of potential drug-drug interactions (pDDIs). Therefore, in this study the prevalence, levels (severity and documentation), predictors (risk factors), and clinical relevance of pDDIs among inpatients diagnosed with pneumonia have been investigated.
\end{abstract}

Methods: Clinical records of 431 hospitalized patients with pneumonia were checked for pDDls using drug interactions screening software (Micromedex-DrugReax). Odds-ratios for predictors were calculated using logistic regression analysis. Clinical relevance of pDDls was assessed by evaluation of patients' clinical profiles for potential adverse outcomes of the most frequent pDDls. Abnormal patients' signs/symptoms and laboratory investigations indicating adverse outcomes of interactions were reported.

Results: Of total 431 profiles, pDDls were reported in $73.1 \%$. Almost half of the profiles were having majorpDDIs (53.8\%). Total number of pDDls were 1318, of which 606 were moderate- and 572 were major-pDDls. Patient's profiles identified with the most frequent interactions were presented with signs, symptoms, and abnormalities in labs indicating decrease therapeutic response, electrolyte abnormalities, hypoglycemia, bleeding, hepatotoxicity, and hypertension. These adverse events were more prevalent in patients taking higher doses of the interacting drugs as compared to lower doses. Logistic regression analysis revealed significant association for major-pDDIs with 6-10 prescribed medicines $(\mathrm{OR}=26.1 ; p=0.002)$, $>10$ prescribed medicines $(\mathrm{OR}=144 ; p<0.001)$, and tuberculosis $(\mathrm{OR}=8.2 ; p=0.004)$.

Conclusions: PDDIs are highly prevalent in patients with pneumonia. Most frequent and clinically important pDDls need particular attention. Polypharmacy and tuberculosis increase the risk of pDDls. Identifying patients more at risk to pDDls and careful monitoring of pertinent signs/symptoms and laboratory investigations are important measures to reduce pDDIs and their related adverse consequences.

Keywords: Pneumonia, Patient safety, Pneumonia therapy, Potential drug-drug interactions, Clinical relevance, Polypharmacy

\footnotetext{
* Correspondence: ismailrph@uop.edu.pk

Department of Pharmacy, University of Peshawar, Peshawar, Khyber

Pakhtunkhwa, Pakistan
}

(c) The Author(s). 2019 Open Access This article is distributed under the terms of the Creative Commons Attribution 4.0 International License (http://creativecommons.org/licenses/by/4.0/), which permits unrestricted use, distribution, and reproduction in any medium, provided you give appropriate credit to the original author(s) and the source, provide a link to the Creative Commons license, and indicate if changes were made. The Creative Commons Public Domain Dedication waiver (http://creativecommons.org/publicdomain/zero/1.0/) applies to the data made available in this article, unless otherwise stated. 


\section{Background}

Worldwide, pneumonia remains the leading cause for childhood mortality and adult hospitalization, regardless of progresses in the management and preventive policies [1]. According to World Health Organization, in 2015 pneumonia causes death for approximately 920,136 children, accounting for $16 \%$ of all deaths of children younger than 5 years [2]. Pneumonia is considered as one of the contributing factors causing burden on health care system [3].

Pneumonia patients are usually hospitalized due to severe nature of the disease or for the management of comorbid illnesses or associated symptoms. The leading comorbidities of patients with pneumonia include diabetes mellitus, cerebrovascular disease, chronic lung disease, chronic kidney disease, and dementia [4]. During hospitalization such patients are prescribed with antipyretics, antitussives, antibiotics, and antihistamines [5]. Apart from the use of aforementioned drugs, such patients are prescribed with a large number of other drugs for the management of associated symptoms and comorbid illnesses [6]. There is an increased risk of drug-drug interactions (DDIs) with simultaneous use of multiple drugs. DDIs may lead to alteration in the pharmacokinetic parameters or pharmacodynamic profile of drugs $[7,8]$. Many of the negative clinical consequences such as decreased or abolished clinical effectiveness, adverse drug reactions (ADRs), toxicity, hospitalization, and prolonged hospital stay are attributed by DDIs [9]. DDIs lead to $20-30 \%$ of adverse effects, of which $1-2 \%$ are life-threatening and $70 \%$ need clinical intervention [10]. Studies have usually addressed the issue of potential DDIs (pDDIs) either in a general way or on the basis of clinical specialties such as geriatrics [8], internal medicine [11], oncology [12], psychiatry [13], and cardiology [14]. Despite being one of the most frequent causes of hospitalization [15], DDIs specifically among hospitalized patients with pneumonia in clinical settings remain unaddressed. Therefore, particular attention is needed in order to conduct studies regarding pDDIs and their clinical relevance among hospitalized patients with pneumonia. Subsequently, such studies will help health care professionals to manage pDDIs and reduce their associated consequences, improve patients' safety, and bring positive clinical outcomes.

Therefore, in this study the prevalence, levels (severity and documentation), predictors (risk factors), and clinical relevance of pDDIs among inpatients diagnosed with pneumonia have been investigated.

\section{Methods}

\section{Study design and settings}

The present study was carried out in internal medicine wards at tertiary care settings (KTH: Khyber
Teaching Hospital and HMC: Hayatabad Medical Complex) of the provincial capital (KPK, Khyber Pakhtunkhwa) using a cross-sectional retrospective design. Khyber Teaching Hospital is located at the main university road of the provincial capital, while Hayatabad Medical Complex is located in the Town III of the city. Khyber Teaching Hospital delivers health care and referral services to the residents of Peshawar University Town and adjacent areas, while Hayatabad Medical Complex provides services to the western parts of Peshawar, its neighboring areas, and patients coming from Afghanistan. Both the hospitals are lacking clinical pharmacy services at the level of the wards. Moreover, software-based drug interactions screening programs are lacking in both the hospitals. Patients' data are maintained in the predesigned charts and kept in the main record room of the hospitals.

\section{Inclusion and exclusion criteria}

The study included inpatients diagnosed with pneumonia during the study period (from 1-Jan-15 to 31-Dec-16), and of either gender and age. Patients' profiles lacking relevant data required for the study were excluded.

\section{Sample size calculation}

The calculated sample size was 383 based on the anticipated prevalence of $52.8 \%$ [15], 95\% confidence level, and 5\% margin of error [16]. However, total 431 patients were eligible for inclusion during the study period (from January 2015 to December 2016); therefore, all were included.

\section{Data source}

Administrative permission was obtained from both the hospitals for the access of patients' clinical record. Convenient sampling technique was used for collecting the following data: patients' demographics, hospital admissions and discharge dates, diagnoses, comorbidities, medications therapy at the hospital, signs/symptoms, and laboratory tests.

\section{Screening for pDDls}

Micromedex Drug-Reax ${ }^{\oplus}$ [17] was used for checking patients' medications profiles for the identification of DDIs. This software classifies DDIs according to severity- and documentation-levels [17]. The detail description of these levels is available elsewhere [18-20].

Prevalence of pDDIs as well as prevalence of severitylevels were identified. List of the most frequent (widespread) and clinically important pDDIs was provided. The list also includes potential adverse consequences and levels (severity as well as documentation) of such pDDIs. 


\section{Clinical relevance of pDDIs}

Clinical relevance of pDDIs was assessed by evaluating each patient's profile for potential adverse outcomes of top-10 pDDIs. Abnormal patients' signs/symptoms and laboratory tests indicating adverse outcomes of interactions were reported. The clinical features were stratified based on dose differences of interacting drugs. The following cut off points were used for defining higher daily doses, furosemide: $\geq 60 \mathrm{mg}$; hydrocortisone: $\geq 500 \mathrm{mg}$; aspirin: $\geq 150 \mathrm{mg}$; insulin: > 20 units; isoniazid: $\geq 150 \mathrm{mg}$; rifampin: $\geq 300 \mathrm{mg}$; calcium containing products: $\geq 1 \mathrm{~g}$; ceftriaxone: $\geq 4$ g; pyrazinamide: $\geq 500 \mathrm{mg}$; ramipril: $\geq 5 \mathrm{mg}$; albuterol: $\geq 15 \mathrm{mg} / 3 \mathrm{ml}$; bisoprolol: $\geq 5 \mathrm{mg}$. In this study, adverse outcomes were defined as follows, increased blood urea nitrogen (BUN): BUN $\leq 20 \mathrm{mg} / \mathrm{dL}$; increased serum creatinine: serum creatinine $>1.06 \mathrm{mg} / \mathrm{dL}$; hypernatremia: serum sodium > $145 \mathrm{mmol} / \mathrm{L}$; hyponatremia: serum sodium $<135 \mathrm{mmol} / \mathrm{L}$; hyperkalemia: serum potassium $>5.5 \mathrm{mmol} /$ $\mathrm{L}$; hypokalemia: serum potassium $<3.5 \mathrm{mmol} / \mathrm{L}$; hyperchloremia: serum chloride $>105 \mathrm{mmol} / \mathrm{L}$; hypertension: systolic blood pressure (BP) $>130 \mathrm{mmHg}$ and/or diastolic $\mathrm{BP}>90 \mathrm{mmHg}$; hypotension: systolic $\mathrm{BP}<80 \mathrm{mmHg}$ and/ or diastolic $\mathrm{BP}<50 \mathrm{mmHg}$; bradycardia: heart rate $<70$ beats/min; tachycardia: heart rate $>100$ beats/min; increased activated partial thromboplastin time (APTT): APTT > $35.5 \mathrm{~s}$; increased prothrombin time (PT): PT > $15.5 \mathrm{~s}$; increased international normalized ratio (INR): INR $>1.2$; decreased platelets: platelets count $<150$, $000 / \mu \mathrm{L}$; hypoglycemia: random blood sugar $<80 \mathrm{mg} / \mathrm{dL}$ or fasting blood sugar $<70 \mathrm{mg} / \mathrm{dL}$; increased alkaline phosphatase: $>126 \mathrm{U} / \mathrm{L}$; increased serum bilirubin: $>1$ $\mathrm{mg} / \mathrm{dL}$; increased alanine aminotransferase: > $59 \mathrm{U} / \mathrm{L}$ (male), > 36 U/L (female); leukocytosis: total leukocyte count $>11,000 / \mu \mathrm{L}$.

\section{Statistical analysis}

Data were presented in frequencies and percentages form and where appropriate median (interquartile range (IQR)) was also provided. Binary logistic regression analysis (both univariate as well as multivariate) with enter method was applied to identify association of various predictors with all interactions as well as major interactions. Presence of drug interactions (overall or major) was taken as dependent variable. Patients characteristics such as gender, age, prescribed medicines, hospitalization, and comorbidities were independent variables in the model. Odds ratios (OR) and 95\% confidence intervals $(\mathrm{CI})$ were calculated to identify the strength of association of each independent variable with pDDIs. Multivariate analyses were carried out for variables with a univariate $p$-value of $\leq 0.15$. $P$-value of $\leq 0.05$ was considered statistically significant. All the data were statistically analyzed using SPSS-v23.

\section{Results}

Patients' general characteristics

Patients' demographics and comorbidities are shown in Table 1 . Of total study subjects, $51 \%$ were males. The median number of prescribed drugs was 11 (8-14) and median hospital stay was 4 days (3-6). Majority of the studied patients were aged $\geq 41$ years $(85.3 \%)$. Most were prescribed with $>10$ drugs $(52 \%)$. Most frequent hospitalization was $\geq 3$ days $(81.7 \%)$. Hypertension $(n=$ 220), diabetes mellitus (120), stroke (120), and chronic obstructive pulmonary disease (37) were the four leading comorbidities of the studied patients.

\section{Prevalence and levels of pDDIs}

Table 2 presents prevalence and levels of pDDIs. Of total 431 pneumonia patients, pDDIs were identified in 315 (73.1\%) patients. In $22.7 \%$ patients, $>4$ pDDIs per patient were found. Based on severity-wise prevalence, $53.8 \%$ patients were presented with major-pDDIs, while 51.5\% with moderate-pDDIs. Patients with contraindicated- and minor-pDDIs were observed in a low frequency. The total recorded pDDIs were categorized based on the levels of severity and documentation. Total number of pDDIs were 1318, of which 606 were moderate- and 572 were majorpDDIs. According to documentation-levels, 690 were fair- and 491 were good-type.

\section{Risk factors of pDDls}

Results regarding exposure to all types- and majorpDDIs stratified with respect to patient's characteristics are presented in Table 3. PDDIs were more common in males as compared to females. Moreover, pDDIs were more frequently found in patients with an age range of 31 to 60 years, prescribed with $>10$ medicines, and $>4$ days hospitalization. Additionally, concerning comorbidities, pDDIs were mostly reported in hypertension, diabetes mellitus, stroke, and ischemic heart disease.

Table 4 presents ORs with corresponding 95\%CIs for pDDIs of all types using univariate model. The results were significant with patient's age $31-60$ years $(\mathrm{OR}=3.5$; $p<0.001) \&>60$ years $(\mathrm{OR}=3 ; p=0.002)$, prescribed with $6-10$ medicines $(\mathrm{OR}=8.3 ; p<0.001)$, $>10$ medicines $(\mathrm{OR}=53.9 ; p<0.001)$, and $>4$ days hospitalization $(\mathrm{OR}=3.1 ; p<0.001)$. Moreover, concerning comorbidities, significant association of all types-pDDIs was found with hypertension $(\mathrm{OR}=1.8 ; p=0.008)$, diabetes mellitus $(\mathrm{OR}=2.6 ; p=0.001)$, stroke $(\mathrm{OR}=1.9 ; p=0.01)$, ischemic heart disease $(\mathrm{OR}=1.9 ; p=0.15)$, and tuberculosis $(\mathrm{OR}=2.8 ; p=0.09)$.

In multivariate model, all types of pDDIs were significantly associated with $6-10$ prescribed medicines $(\mathrm{OR}=$ 7.3; $p<0.001)$, and $>10$ prescribed medicines $(\mathrm{OR}=$ 43.3; $p<0.001$ ) (Table 4). 
Table 1 General characteristics of study patients $(n=431)$

\begin{tabular}{|c|c|}
\hline Characteristic & Patients: $\mathrm{n}\left(\%^{\mathrm{a}}\right)$ \\
\hline \multicolumn{2}{|l|}{ Gender } \\
\hline Male & $220(51)$ \\
\hline Female & $211(49)$ \\
\hline \multicolumn{2}{|l|}{ Age (years) } \\
\hline$\leq 40$ & $63(14.6)$ \\
\hline $41-60$ & $176(40.8)$ \\
\hline$>60$ & $192(44.5)$ \\
\hline Median (IQR) & $60(50-70)$ \\
\hline \multicolumn{2}{|l|}{ Drugs prescribed per patient } \\
\hline$\leq 5$ & $42(9.7)$ \\
\hline $6-10$ & $165(38.3)$ \\
\hline$>10$ & $224(52)$ \\
\hline Median (IQR) & $11(8-14)$ \\
\hline \multicolumn{2}{|l|}{ Hospital stay (days) } \\
\hline$\leq 2$ & 79 (18.3) \\
\hline $3-4$ & $143(33.2)$ \\
\hline$>4$ & $209(48.5)$ \\
\hline Median (IQR) & $4(3-6)$ \\
\hline \multicolumn{2}{|l|}{ Number of comorbidities } \\
\hline No comorbidities & $24(5.6)$ \\
\hline $1-2$ & $170(39.4)$ \\
\hline $3-4$ & $127(29.4)$ \\
\hline 5 & $10(2.3)$ \\
\hline \multicolumn{2}{|l|}{ Comorbidities } \\
\hline Hypertension & $220(51)$ \\
\hline Diabetes mellitus & $120(27.8)$ \\
\hline Stroke & $120(27.8)$ \\
\hline Chronic obstructive pulmonary disease & $37(8.6)$ \\
\hline Ischemic heart disease & $36(8.3)$ \\
\hline Urinary tract infection & $34(7.9)$ \\
\hline Tuberculosis & $25(5.8)$ \\
\hline Hepatitis & $24(5.6)$ \\
\hline Chronic kidney disease & $20(4.6)$ \\
\hline Asthma & $16(3.7)$ \\
\hline Congestive cardiac failure & $14(3.2)$ \\
\hline Post tuberculosis bronchiectasis & $12(2.8)$ \\
\hline Malaria & $10(2.3)$ \\
\hline Decompensated chronic liver disease & $10(2.3)$ \\
\hline Left ventricular failure & $9(2.1)$ \\
\hline Miscellaneous & $167(38.7)$ \\
\hline
\end{tabular}

IQR Interquartile range

aPercentage was calculated out of total number of patients i.e., 431
Table 2 Prevalence and levels of potential drug-drug interactions

\begin{tabular}{ll}
\hline PDDls & Patients: $\mathrm{n}(\%)$ \\
\hline Prevalence of pDDls ${ }^{\mathrm{a}}$ & \\
Overall prevalence of pDDls & \\
Number of pDDls per patient & $143.1)$ \\
$1-2$ & $76(17.6)$ \\
$3-4$ & $98(22.7)$ \\
$>4$ & \\
Severity-wise prevalence of pDDIs & $47(10.9)$ \\
Contraindicated & $232(53.8)$ \\
Major & $222(51.5)$ \\
Moderate & $74(17.1)$ \\
Minor & \\
Levels of pDDIs & \\
Severity-levels & \\
$\quad$ Contraindicated & $50(3.8)$ \\
Major & $572(43.4)$ \\
Moderate & $606(46)$ \\
Minor & $90(6.8)$ \\
Documentation-levels & \\
Excellent & $137(10.4)$ \\
Good & $491(37.2)$ \\
\hline
\end{tabular}

PDD/s Potential drug-drug interactions

aPercentage was calculated out of total number of patients i.e., 431

${ }^{b}$ Percentage was calculated out of total number of potential drug-drug interactions i.e., 1318

Overall-prevalence is the occurrence of at least one pDDI irrespective of severity type. Total number of pneumonia patients were 431. Therefore, overall-prevalence of pDDls was $73.1 \%$ (315 out of 431 )

Table 4 further presents logistic regression analysis for exposure to major-pDDIs. The univariate logistic regression analysis showed significant association with patients age $31-60$ years $(\mathrm{OR}=2.8 ; p=0.006) \&>60$ years $(\mathrm{OR}=$ $2.3 ; p=0.02)$, prescribed with $6-10$ medicines $(\mathrm{OR}=$ 23.4; $p=0.002),>10$ medicines $(\mathrm{OR}=132.3 ; p<0.001)$, and hospital stay of $3-4$ days $(\mathrm{OR}=1.8 ; p=0.04) \&>4$ days $(\mathrm{OR}=3.2 ; p<0.001)$. Moreover, concerning comorbidities, significant association of major-pDDIs was found with hypertension $(\mathrm{OR}=1.4 ; p=0.07)$, diabetes mellitus ( $\mathrm{OR}=1.8 ; p=0.008)$, stroke ( $\mathrm{OR}=1.6 ; p=0.03)$, ischemic heart disease $(\mathrm{OR}=2.1 ; p=0.05)$, and tuberculosis $(\mathrm{OR}=4.8 ; p=0.004)$.

In multivariate model, association of major-pDDIs remained significant with $6-10$ prescribed medicines $(\mathrm{OR}=$ $26.1 ; p=0.002),>10$ prescribed medicines $(\mathrm{OR}=144$; $p<0.001)$, and tuberculosis $(\mathrm{OR}=8.2 ; p=0.004)$ (Table 4).

\section{Widespread interacting drug pairs}

Most commonly identified and clinically important pDDIs are shown in Table 5. Potential adverse consequences of 
Table 3 Exposure to all types- and major-pDDls stratified with respect to patients' characteristics

\begin{tabular}{|c|c|c|}
\hline \multirow[t]{2}{*}{ Patient's characteristics } & \multirow{2}{*}{$\begin{array}{l}\text { All types of } \\
\text { interactions } \\
\text { Patients: } \\
\mathrm{n}(\%)\end{array}$} & \multirow{2}{*}{$\begin{array}{l}\text { Only major } \\
\text { interactions } \\
\text { Patients: } \\
\text { n (\%) }\end{array}$} \\
\hline & & \\
\hline \multicolumn{3}{|l|}{ Gender } \\
\hline Male & $162(51.4)$ & $121(52.2)$ \\
\hline Female & $153(48.6)$ & $111(47.8)$ \\
\hline \multicolumn{3}{|l|}{ Age (years) } \\
\hline$\leq 30$ & $19(6)$ & $13(5.6)$ \\
\hline $31-60$ & $154(48.9)$ & $116(50)$ \\
\hline$>60$ & $142(45.1)$ & $103(44.4)$ \\
\hline \multicolumn{3}{|l|}{ Drugs prescribed per patient } \\
\hline$\leq 5$ & $7(2.2)$ & $1(0.4)$ \\
\hline $6-10$ & $103(32.7)$ & $60(25.9)$ \\
\hline$>10$ & $205(65.1)$ & $171(73.7)$ \\
\hline \multicolumn{3}{|l|}{ Hospital stay (days) } \\
\hline$\leq 2$ & $47(14.9)$ & $28(12.1)$ \\
\hline $3-4$ & $97(30.8)$ & $71(30.6)$ \\
\hline$>4$ & $171(54.3)$ & $133(57.3)$ \\
\hline \multicolumn{3}{|l|}{ Comorbidities } \\
\hline Hypertension & $173(54.9)$ & $128(55.2)$ \\
\hline Diabetes mellitus & $102(32.4)$ & $77(33.2)$ \\
\hline Stroke & $98(31.1)$ & $75(32.3)$ \\
\hline Chronic obstructive pulmonary disease & $25(7.9)$ & $13(5.6)$ \\
\hline Ischemic heart disease & $30(9.5)$ & $25(10.8)$ \\
\hline Urinary tract infection & $25(7.9)$ & $21(9.1)$ \\
\hline Tuberculosis & $22(7)$ & $21(9.1)$ \\
\hline Hepatitis & $16(5.1)$ & $11(4.7)$ \\
\hline Chronic kidney disease & $16(5.1)$ & $9(3.9)$ \\
\hline Asthma & $14(4.4)$ & $10(4.3)$ \\
\hline
\end{tabular}

such interactions were nephrotoxicity, hypokalemia, bleeding, hypoglycemia or hyperglycemia, hepatotoxicity, reduction in therapeutic effectiveness, hypertension, hypotension, gastrointestinal ulceration, QT interval prolongation, and hyperkalemia.

\section{Clinical relevance of pDDIs}

Prescribed doses and administration frequencies of the interacting drugs are shown in Table 6. Drugs were given in a variety of the doses and administration frequencies. Following interacting drugs were prescribed with lower doses such as: aspirin, furosemide, clopidogrel, isoniazid, rifampin, pyrazinamide, calcium containing products, ceftriaxone, ramipril, and bisoprolol. While, following drugs were prescribed with higher doses such as: hydrocortisone, insulin, and albuterol. Lower doses of the interacting drugs were more frequent as compared to higher doses.

Table 7 shows pertinent clinical features (signs/symptoms and laboratory tests) in lower and higher doses groups for top-10 pDDIs. Clinical manifestations suggesting low drug's efficacy and electrolytes abnormalities were found in patients with the interactions; aspirin + furosemide, calcium containing products + ceftriaxone, and aspirin + ramipril. These features were highly reported among patients with higher doses of furosemide, ceftriaxone, and ramipril. In patients with the interactions furosemide + hydrocortisone and albuterol + furosemide; signs/symptoms of hypokalemia such as tachycardia, constipation, confusion, irregular heart rate, nausea, and vomiting were observed. The signs/symptoms of hypokalemia were highly prevalent among low dose groups of furosemide + hydrocortisone, and high dose groups of furosemide + albuterol. Signs/symptoms and abnormalities in labs suggesting bleeding were found in patients with the interaction, aspirin + clopidogrel. Such patients were prescribed more frequently with low doses of both clopidogrel and aspirin. Signs/symptoms and abnormalities in labs indicating hypoglycemia were more prevalent in patients with the interaction aspirin + insulin and prescribed with high doses of the insulin. Moreover, signs/symptoms and abnormalities in labs suggesting hepatotoxicity were more prevalent among patients with the interactions; isoniazid + rifampin, pyrazinamide + rifampin, and prescribed with high doses of these interacting drugs. Additionally, signs/ symptoms of HTN were more frequently reported among high dose groups of aspirin + bisoprolol. Monitoring/management guidelines for top-10 pDDIs are also provided in Table $7[17,21]$.

\section{Discussion}

The issue of drug interactions remains one of the considerable factors among hospitalized patients [7]. This report presents the prevalence, categorization, risk factors, and clinical relevance of pDDIs among hospitalized pneumonia patients. The area remains poorly addressed, locally as well as globally, therefore such studies are needed. The overall prevalence of pDDIs in the current study was higher $(73.1 \%)$ as compared with that among patients with certain diseases such as HIV (52.2\%) [22], liver cirrhosis (21.5\%) [23], hypertension (48\%) [24], and pediatric patients with respiratory diseases (38.9\%) [25]. While, this prevalence of pDDIs is lower in comparison with that among patients with chronic obstructive pulmonary disease (90\%) [26] and hemodialysis (89.1\%) [27]. Moreover, in our sample, prevalence of majorpDDIs was higher (53.8\%) in comparison to that among patients with chronic obstructive pulmonary disease (20\% at hospital admission and $24 \%$ at hospital discharge) 
Table 4 Logistic regression analysis based on exposure to all types- and major-pDDIs

\begin{tabular}{|c|c|c|c|c|c|c|c|c|}
\hline \multirow[t]{3}{*}{ Variables } & \multicolumn{4}{|c|}{ All types-pDDIs ${ }^{a}$} & \multicolumn{4}{|l|}{ Major-pDDIs $^{\mathrm{b}}$} \\
\hline & \multicolumn{2}{|c|}{ Univariate analysis } & \multicolumn{2}{|c|}{ Multivariate analysis } & \multicolumn{2}{|c|}{ Univariate analysis } & \multicolumn{2}{|c|}{ Multivariate analysis } \\
\hline & OR $(95 \% \mathrm{Cl})$ & $p$-value & OR $(95 \% \mathrm{Cl})$ & $p$-value & OR $(95 \% \mathrm{Cl})$ & $p$-value & OR $(95 \% \mathrm{Cl})$ & $p$-value \\
\hline \multicolumn{9}{|l|}{ Gender } \\
\hline Male & Reference & & - & & Reference & & - & \\
\hline Female & $0.9(0.6-1.4)$ & 0.8 & - & - & $0.9(0.6-1.3)$ & 0.6 & - & - \\
\hline \multicolumn{9}{|l|}{ Age (Years) } \\
\hline$\leq 30$ & Reference & & Reference & & Reference & & Reference & \\
\hline $31-60$ & $3.5(1.7-7.2)$ & $<0.001$ & $1.9(0.7-4.7)$ & 0.2 & $2.8(1.3-5.7)$ & 0.006 & $2.1(0.8-5.7)$ & 0.1 \\
\hline$>60$ & $3(1.5-6)$ & 0.002 & $1.5(0.6-3.9)$ & 0.4 & $2.3(1.1-4.8)$ & 0.02 & $1.7(0.6-4.5)$ & 0.3 \\
\hline \multicolumn{9}{|l|}{ Drugs prescribed } \\
\hline$\leq 5$ & Reference & & Reference & & Reference & & Reference & \\
\hline $6-10$ & $8.3(3.5-20)$ & $<0.001$ & $7.3(2.9-18.4)$ & $<0.001$ & $23.4(3.1-174.7)$ & 0.002 & $26.1(3.3-210)$ & 0.002 \\
\hline$>10$ & $53.9(21-138)$ & $<0.001$ & $43.3(15.6-120)$ & $<0.001$ & $132.3(18-985)$ & $<0.001$ & $144(18-1177)$ & $<0.001$ \\
\hline \multicolumn{9}{|l|}{ Hospital stay (days) } \\
\hline$\leq 2$ & Reference & & Reference & & Reference & & Reference & \\
\hline $3-4$ & $1.4(0.8-2.5)$ & 0.2 & $0.7(0.3-1.3)$ & 0.3 & $1.8(1-3.2)$ & 0.04 & $0.8(0.4-1.6)$ & 0.5 \\
\hline$>4$ & $3.1(1.7-5.4)$ & $<0.001$ & $0.9(0.5-2)$ & 0.9 & $3.2(1.9-5.5)$ & $<0.001$ & $0.9(0.5-1.9)$ & 0.9 \\
\hline \multicolumn{9}{|l|}{ Comorbidities } \\
\hline Hypertension & $1.8(1.2-2.8)$ & 0.008 & $0.9(0.5-1.7)$ & 0.9 & $1.4(0.9-2.1)$ & 0.07 & $0.9(0.5-1.5)$ & 0.5 \\
\hline Diabetes mellitus & $2.6(1.5-4.5)$ & 0.001 & $1.8(0.9-3.5)$ & 0.08 & $1.8(1.2-2.8)$ & 0.008 & $1.2(0.7-2.1)$ & 0.5 \\
\hline Stroke & $1.9(1.1-3.3)$ & 0.01 & $1.5(0.8-2.9)$ & 0.19 & $1.6(1.1-2.5)$ & 0.03 & $1.4(0.8-2.5)$ & 0.2 \\
\hline Chronic obstructive pulmonary disease & $0.7(0.4-1.5)$ & 0.4 & - & - & $0.4(0.2-0.9)$ & 0.02 & $0.4(0.2-0.9)$ & 0.03 \\
\hline Ischemic heart disease & $1.9(0.8-4.8)$ & 0.15 & $1.3(0.5-3.6)$ & 0.6 & $2.1(0.9-4.3)$ & 0.05 & $1.8(0.8-4.4)$ & 0.2 \\
\hline Urinary tract infection & $1(0.5-2.3)$ & 0.9 & - & - & $1.4(0.7-2.9)$ & 0.3 & - & - \\
\hline Tuberculosis & $2.8(0.8-9.6)$ & 0.09 & $3.7(0.9-16.2)$ & 0.08 & $4.8(1.6-14.4)$ & 0.004 & $8.2(1.9-34.7)$ & 0.004 \\
\hline Hepatitis & $0.7(0.3-1.7)$ & 0.5 & - & - & $0.7(0.3-1.6)$ & 0.4 & - & - \\
\hline Chronic kidney disease & $1.5(0.5-4.6)$ & 0.5 & - & - & $0.7(0.3-1.7)$ & 0.4 & - & - \\
\hline Asthma & $2.7(0.6-11.8)$ & 0.2 & - & - & $1.4(0.5-4.1)$ & 0.5 & - & - \\
\hline
\end{tabular}

pDD/s Potential drug-drug interactions

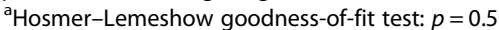

${ }^{b}$ Hosmer-Lemeshow goodness-of-fit test: $p=0.7$

[26], liver cirrhosis (21.4\%) [23], hepatitis C (30-44\%) [28], and pediatric patients with respiratory diseases (9.5\%) [25]. Regardless of variations in the study design, study population, drug utilization/prescribing pattern, consideration of pDDIs types, and drug interaction screening software, our findings indicated higher prevalence of pDDIs. Based on the current findings, patients with pneumonia are at higher risk to DDIs. Therefore, to minimize, prevent, or manage DDIs in hospitals settings following evidence-based strategies have been suggested: use of computerized screening programs for screening medications profiles for pDDIs [29], involving clinical pharmacist for the assessment of pDDIs [11, 13, 30], method for structured evaluation of pDDIs [31], and appraisal of pertinent labs investigations for clinical relevance of interactions [7, 32].
Identifying the type of pDDIs by health care professionals is necessary for the management of adverse events related to pDDIs, reducing/preventing the associated risk, and clinical management of pDDIs. In this study, pDDIs of moderate- and major-severity were frequently identified. Concerning documentation-levels, fair- and good-type were highly prevalent. Similar findings were observed by other studies among hospitalized patients $[14,15,24]$. These findings warrant pneumonia patients to be at risk for the pDDIs associated adverse consequences. Such patients should be monitored for any negative clinical consequences expected due to DDIs.

Polypharmacy is a considerable issue in hospitalized patients with pneumonia [5]. It refers to prescribing more than five drugs at a time [33, 34]. Pneumonia 
Table 5 Description of the top-20 and clinically important potential drug-drug interactions in patients with pneumonia

\begin{tabular}{|c|c|c|c|c|}
\hline Interacting pairs & Frequency & Severity & Documentation & Potential adverse outcomes \\
\hline Aspirin - Furosemide & 40 & Major & Good & $\begin{array}{l}\text { Reduced diuretic effectiveness and possible } \\
\text { nephrotoxicity }\end{array}$ \\
\hline Furosemide - Hydrocortisone & 39 & Moderate & Fair & Hypokalemia \\
\hline Aspirin - Clopidogrel & 37 & Major & Fair & Increased risk of bleeding \\
\hline Aspirin - Insulin & 33 & Moderate & Fair & Hypoglycemia \\
\hline Isoniazid - Rifampin & 33 & Major & Good & Hepatotoxicity \\
\hline Calcium containing products - Ceftriaxone & 33 & Contraindicated & Good & $\begin{array}{l}\text { Formation of ceftriaxone-calcium precipitates and is } \\
\text { contraindicated in neonates }\end{array}$ \\
\hline Pyrazinamide - Rifampin & 32 & Major & Good & Hepatotoxicity \\
\hline Aspirin - Ramipril & 28 & Moderate & Fair & Decreased ramipril effectiveness \\
\hline Albuterol - Furosemide & 28 & Moderate & Fair & ECG changes or hypokalemia \\
\hline Aspirin - Bisoprolol & 23 & Moderate & Good & Increased blood pressure \\
\hline Furosemide - Ramipril & 23 & Moderate & Good & Postural hypotension (first dose) \\
\hline Clarithromycin - Dexamethasone & 23 & Major & Fair & $\begin{array}{l}\text { Decrease clarithromycin exposure and increased } \\
\text { dexamethasone exposure }\end{array}$ \\
\hline Aspirin - Dexamethasone & 21 & Moderate & Good & $\begin{array}{l}\text { Increased risk of gastrointestinal ulceration and } \\
\text { subtherapeutic aspirin serum concentrations }\end{array}$ \\
\hline Aspirin - Nitroglycerin & 20 & Moderate & Good & $\begin{array}{l}\text { Increase in nitroglycerin concentrations and additive } \\
\text { platelet function depression }\end{array}$ \\
\hline Clopidogrel - Esomeprazole & 17 & Major & Excellent & $\begin{array}{l}\text { Reduced plasma concentrations of clopidogrel active } \\
\text { metabolite and reduced antiplatelet activity }\end{array}$ \\
\hline Azithromycin - Moxifloxacin & 16 & Major & Fair & Increased risk of QT-interval prolongation \\
\hline Aspirin - Spironolactone & 16 & Major & Good & $\begin{array}{l}\text { Reduced diuretic effectiveness, hyperkalemia, or possible } \\
\text { nephrotoxicity }\end{array}$ \\
\hline Clopidogrel - Omeprazole & 13 & Major & Excellent & $\begin{array}{l}\text { Reduced plasma concentrations of clopidogrel active } \\
\text { metabolite and reduced antiplatelet activity }\end{array}$ \\
\hline Omeprazole - Rifampin & 13 & Moderate & Fair & Decreased omeprazole plasma concentrations \\
\hline Ramipril - Spironolactone & 13 & Major & Good & Hyperkalemia \\
\hline
\end{tabular}

patients receive co-prescription of a number of medicines for the treatment of comorbidities or associated symptoms [5, 6]. A positive relationship of polypharmacy with pDDIs reported by our study is supported by previous published studies [12, 14, 35, 36]. Moreover, in this study separate odds of exposure to major-pDDIs have been calculated. The findings of statistically significant relationship of major-pDDIs with polypharmacy are consistent with findings from previous studies [36, 37]. In addition, we found significant association of majorpDDIs with tuberculosis. The possible reason is prescription of anti-TB drugs among patients with $\mathrm{TB}$ and these drugs are responsible for a large number of clinically important DDIs [38]. In this regard, hospitalized patients with pneumonia are at increased risk to pDDIs due to these predictors. Health care professionals should have knowledge regarding all predictors increasing the risk of pDDIs to individualize patients more at risk, optimize medications therapy, and minimize or prevent pDDIs.
PDDIs of any type of severity are not clinically important. So, developing list of clinically important and most frequently observed interactions is of immense need. The list will be used by physicians and pharmacists for the development of therapeutic guidelines and timely/selective identification of pDDIs. A physician's understanding and knowledge of DDIs can reduce the occurrence of associated adverse events, adjust therapeutic regimen of high-risk patients, provide better quality care, and prevent associated medico-legal concerns. In this study, potential adverse consequences of the most frequent pDDIs were nephrotoxicity, hypokalemia, bleeding, hypoglycemia, hepatotoxicity, reduction in therapeutic effectiveness, hypotension, QT interval prolongation, and hyperkalemia. These findings are somehow consistent with findings of a study on hospitalized patients with liver cirrhosis in which most prevalent potential adverse outcomes due to pDDIs were hyperkalemia, hypoglycemia, renal function deterioration, QT interval prolongation, and bleeding risk [23]. 
Table 6 Prescribed drugs' doses of the top-10 interactions

\begin{tabular}{|c|c|c|c|}
\hline Interacting pair & Dose categories $^{a}$ & Prescribed dose regimen & Number of patients \\
\hline \multirow[t]{7}{*}{ Aspirin + Furosemide } & Low + Low & 75 mg OD + 40 mg OD & 17 \\
\hline & Low + High & 75 mg OD + 60 mg OD & 10 \\
\hline & Low + Low & 75 mg OD + 20 mg OD & 5 \\
\hline & Low + High & 75 mg OD + 100 mg OD & 3 \\
\hline & Low + High & 75 mg OD + 40 mg BD & 2 \\
\hline & Low + High & 75 mg OD + 60 mg BD & 2 \\
\hline & Low + High & 75 mg OD + 80 mg OD & 1 \\
\hline \multirow[t]{21}{*}{ Furosemide + Hydrocortisone } & Low + High & 40 mg OD + 100 mg QID & 5 \\
\hline & High + High & 80 mg OD + 100 mg QID & 4 \\
\hline & Low + Low & 40 mg OD + 250 mg OD & 3 \\
\hline & High + Low & 60 mg OD + 50 mg QID & 3 \\
\hline & High + High & 60 mg OD + 100 mg QID & 3 \\
\hline & Low + High & 20 mg OD + 100 mg QID & 3 \\
\hline & Low + High & 20 mg OD + 500 mg OD & 2 \\
\hline & Low + Low & 40 mg OD + 50 mg QID & 2 \\
\hline & High + Low & 60 mg OD + 250 mg OD & 2 \\
\hline & High + Low & 40 mg BD + 50 mg BD & 1 \\
\hline & Low + High & $40 \mathrm{mg}$ OD + $250 \mathrm{mg}$ TDS & 1 \\
\hline & High + High & $60 \mathrm{mg} \mathrm{OD}+500 \mathrm{mg}$ TDS & 1 \\
\hline & High + Low & $60 \mathrm{mg} \mathrm{BD}+100 \mathrm{mg}$ TDS & 1 \\
\hline & Low + Low & 40 mg OD + 100 mg BD & 1 \\
\hline & High + Low & 60 mg OD + 100 mg BD & 1 \\
\hline & High + High & 80 mg BD + 100 mg QID & 1 \\
\hline & High + Low & 60 mg BD + 250 mg OD & 1 \\
\hline & High + Low & 80 mg OD + 250 mg OD & 1 \\
\hline & High + High & 100 mg OD + 100 mg QID & 1 \\
\hline & High + High & 80 mg OD + 500 mg QID & 1 \\
\hline & High + Low & $60 \mathrm{mg}$ BD + $50 \mathrm{mg}$ TDS & 1 \\
\hline \multirow[t]{3}{*}{ Aspirin + Clopidogrel } & Low + Low & 75 mg OD + 75 mg OD & 35 \\
\hline & High + Low & 150 mg OD + 75 mg OD & 1 \\
\hline & High + Low & 300 mg OD + 75 mg OD & 1 \\
\hline \multirow[t]{4}{*}{ Aspirin + Insulin } & Low + High & 75 mg OD + 20-40 units/day & 21 \\
\hline & Low + High & 75 mg OD + > 40 units/day & 6 \\
\hline & Low + Low & 75 mg OD $+<20$ units/day & 5 \\
\hline & High + Low & 150 mg OD + 20 units/day & 1 \\
\hline \multirow[t]{2}{*}{ Isoniazid + Rifampin } & Low + Low & 75 mg OD + 150 mg OD & 27 \\
\hline & High + High & 150 mg OD + 300 mg OD & 6 \\
\hline \multirow[t]{7}{*}{ Calcium containing products + Ceftriaxone } & Low + Low & 200 mg/L OD + 2 g OD ATD & 7 \\
\hline & Low + High & 200 mg/L BD + 2 g BD ATD & 5 \\
\hline & Low + Low & 200 mg/L BD + 2 g OD ATD & 4 \\
\hline & High + Low & $1 \mathrm{~g} \mathrm{OD}+2 \mathrm{~g}$ OD ATD & 4 \\
\hline & Low + Low & 200 mg/L OD + 1 g BD ATD & 3 \\
\hline & Low + Low & 200 mg/L TDS + 2 g OD ATD & 2 \\
\hline & High + High & $1 \mathrm{~g} \mathrm{OD}+2 \mathrm{~g} \mathrm{BD}$ ATD & 1 \\
\hline
\end{tabular}


Table 6 Prescribed drugs' doses of the top-10 interactions (Continued)

\begin{tabular}{|c|c|c|c|}
\hline Interacting pair & Dose categories $^{a}$ & Prescribed dose regimen & Number of patients \\
\hline & Low + Low & $200 \mathrm{mg} / \mathrm{L} \mathrm{BD}+1 \mathrm{~g}$ BD ATD & 1 \\
\hline & Low + Low & $200 \mathrm{mg} / \mathrm{L} \mathrm{OD}+1 \mathrm{~g}$ OD ATD & 1 \\
\hline & Low + Low & $200 \mathrm{mg} / \mathrm{L} \mathrm{BD}+1 \mathrm{~g}$ OD ATD & 1 \\
\hline & Low + High & $200 \mathrm{mg} / \mathrm{L} \mathrm{BD}+3 \mathrm{~g}$ BD ATD & 1 \\
\hline & Low + High & $200 \mathrm{mg} / \mathrm{L} \mathrm{OD}+4 \mathrm{~g}$ OD ATD & 1 \\
\hline & High + High & $1250 \mathrm{mg}$ BD + $2 \mathrm{~g}$ BD ATD & 1 \\
\hline & High + Low & $1250 \mathrm{mg}$ OD + $2 \mathrm{~g}$ OD ATD & 1 \\
\hline \multirow[t]{2}{*}{ Pyrazinamide + Rifampin } & Low + Low & $400 \mathrm{mg} \mathrm{OD}+150 \mathrm{mg} \mathrm{OD}$ & 28 \\
\hline & High + High & $500 \mathrm{mg} \mathrm{OD}+300 \mathrm{mg} \mathrm{OD}$ & 4 \\
\hline \multirow[t]{4}{*}{ Aspirin + Ramipril } & Low + Low & $75 \mathrm{mg} \mathrm{OD}+2.5 \mathrm{mg} \mathrm{OD}$ & 20 \\
\hline & Low + High & $75 \mathrm{mg} \mathrm{OD}+5 \mathrm{mg} \mathrm{OD}$ & 4 \\
\hline & Low + High & 75 mg OD + 10 mg OD & 3 \\
\hline & Low + Low & $75 \mathrm{mg} \mathrm{OD}+1.25 \mathrm{mg} \mathrm{OD}$ & 1 \\
\hline \multirow[t]{6}{*}{ Albuterol + Furosemide } & High + Low & $5 \mathrm{mg} / \mathrm{ml} \mathrm{TDS}+40 \mathrm{mg}$ OD & 13 \\
\hline & High + High & $5 \mathrm{mg} / \mathrm{ml}$ TDS + $60 \mathrm{mg} \mathrm{OD}$ & 8 \\
\hline & High + Low & $5 \mathrm{mg} / \mathrm{ml}$ TDS + $20 \mathrm{mg}$ OD & 4 \\
\hline & High + High & $5 \mathrm{mg} / \mathrm{ml}$ TDS + $40 \mathrm{mg} \mathrm{BD}$ & 1 \\
\hline & Low + Low & $50 \mathrm{mcg} /$ actuation TDS + $40 \mathrm{mg}$ OD & 1 \\
\hline & Low + High & $2 \mathrm{mg} \mathrm{OD}+80 \mathrm{mg} B D$ & 1 \\
\hline \multirow[t]{4}{*}{ Aspirin + Bisoprolol } & Low + Low & $75 \mathrm{mg} \mathrm{OD}+2.5 \mathrm{mg} \mathrm{OD}$ & 14 \\
\hline & Low + High & $75 \mathrm{mg} \mathrm{OD}+5 \mathrm{mg} \mathrm{OD}$ & 7 \\
\hline & High + High & 300 mg OD + 5 mg OD & 1 \\
\hline & High + Low & $150 \mathrm{mg} \mathrm{OD}+2.5 \mathrm{mg} \mathrm{OD}$ & 1 \\
\hline
\end{tabular}

$O D$ Once a day, $B D$ Twice a day, QID Four times a day, TDS Three times a day, ATD Alternate day

${ }^{a}$ The following cut off points were used for defining higher daily doses, furosemide: $\geq 60 \mathrm{mg}$; hydrocortisone: $\geq 500 \mathrm{mg}$; aspirin: $\geq 150 \mathrm{mg}$; insulin: $>20$ units; isoniazid: $\geq 150 \mathrm{mg}$; rifampin: $\geq 300 \mathrm{mg}$; calcium containing products: $\geq 1$ g; ceftriaxone: $\geq 4$ g; pyrazinamide: $\geq 500 \mathrm{mg}$; ramipril: $\geq 5 \mathrm{mg}$; albuterol: $\geq 15 \mathrm{mg} / 3 \mathrm{ml}$; bisoprolol: $\geq 5 \mathrm{mg}$

We have related potential adverse effects of DDIs with clinical manifestations of the patients. Such analysis is rarely observed in published literature. Some studies have investigated adverse effects related to interactions but these studies do not specify monitoring parameters and adverse effects for most commonly interacting drug pairs $[23,39]$. This is a novel approach that will be helpful for health care professionals to monitor and manage the adverse outcomes related to interactions. This study also considered doses of the administered drugs. Higher doses of the drugs may potentiate the negative consequences of the interactions. As evident from our findings that adverse events were more prevalent among patients prescribed with higher doses as compared to lower doses. Such considerations give more insight in understanding and management of adverse outcomes of interactions. Furthermore, monitoring parameters and management guidelines will support health care professionals regarding proper assessment and management of drug interactions in pneumonia.

\section{Strengths and limitations}

Following are the potential limitations of this study. The pDDIs recorded in this report are mainly associated with the use of medicines for managing several comorbid illnesses or associated signs/symptoms because of hospitalization of pneumonia patients due to these conditions. Therefore, the findings of this study might not be applicable to ambulatory patients because of variable nature/prevalence of disease and drug interactions. Furthermore, we use the term potential DDIs, as, we do not actually observe DDIs. Data are scarce, concerning negative clinical consequences caused by DDIs, but, some retrospective studies are available in the published literature. One study observed increased odds ratios for digoxin toxicity among patients treated with clarithromycin, for hypoglycemia in patients with cotrimoxazole combined with glyburide, and for hyperkalemia among patients who used ACE inhibitors and potassium-sparing diuretics, concurrently [8]. Another study, reported that, there is five times increase risk 
Table 7 Clinical relevance, dose considerations, and monitoring/management guidelines of top-10 pDDIs in patients with pneumonia

\begin{tabular}{|c|c|c|c|c|}
\hline Interactions $^{a}$ & Dose categories $^{a}$ & $\begin{array}{l}\text { Signs and symptoms and } \\
\text { Laboratory abnormalities }^{\mathrm{b}}\end{array}$ & Patients: $\mathrm{n}\left(\%{ }^{\mathrm{c}}\right)$ & Monitoring/management guidelines \\
\hline \multirow{29}{*}{$\begin{array}{l}\text { Aspirin - } \\
\text { Furosemide (40) }\end{array}$} & \multirow[t]{14}{*}{ Low + Low (21) } & Increased BUN & $14(66.7)$ & \multirow{29}{*}{$\begin{array}{l}\text { Monitoring of aspirin toxicity and renal } \\
\text { function. Response of diuretic should be } \\
\text { checked mainly anti-hypertensive effects. } \\
\text { High doses are generally not } \\
\text { recommended. Alternative may be } \\
\text { considered where possible. }\end{array}$} \\
\hline & & $\begin{array}{l}\text { Increased serum } \\
\text { creatinine }\end{array}$ & $10(47.6)$ & \\
\hline & & Hyponatremia & $7(33.3)$ & \\
\hline & & Hypertension & $6(28.6)$ & \\
\hline & & Dyspnea & $6(28.6)$ & \\
\hline & & Confusion & $5(23.8)$ & \\
\hline & & Drowsiness & $4(19)$ & \\
\hline & & Edema & $2(9.5)$ & \\
\hline & & Hypokalemia & $2(9.5)$ & \\
\hline & & Hyperchloremia & $1(4.8)$ & \\
\hline & & Orthopnea & $1(4.8)$ & \\
\hline & & Chest pain & $1(4.8)$ & \\
\hline & & Nausea & $1(4.8)$ & \\
\hline & & Coma & $1(4.8)$ & \\
\hline & \multirow[t]{15}{*}{ Low + High (19) } & Increased BUN & $16(84.2)$ & \\
\hline & & Hypertension & $13(68.4)$ & \\
\hline & & $\begin{array}{l}\text { Increased serum } \\
\text { creatinine }\end{array}$ & $11(57.9)$ & \\
\hline & & Dyspnea & $7(36.8)$ & \\
\hline & & Hyperchloremia & $6(31.6)$ & \\
\hline & & Chest pain & $5(26.3)$ & \\
\hline & & Orthopnea & $5(26.3)$ & \\
\hline & & Edema & $5(26.3)$ & \\
\hline & & Confusion & $4(21)$ & \\
\hline & & Hypokalemia & $4(21)$ & \\
\hline & & Hyponatremia & $4(21)$ & \\
\hline & & Drowsiness & $2(10.5)$ & \\
\hline & & Hypernatremia & $1(5.3)$ & \\
\hline & & Hyperkalemia & $1(5.3)$ & \\
\hline & & Nausea & $1(5.3)$ & \\
\hline \multirow{12}{*}{$\begin{array}{l}\text { Furosemide - } \\
\text { Hydrocortisone } \\
\text { (39) }\end{array}$} & \multirow[t]{7}{*}{ High + High (11) } & Fever & $7(63.6)$ & \multirow{12}{*}{$\begin{array}{l}\text { Serum potassium level and } \\
\text { cardiovascular status should be } \\
\text { monitored, especially if co-administered. } \\
\text { Patients should be advised to inform } \\
\text { their physician if they experience } \\
\text { potential signs/symptoms of } \\
\text { hypokalemia such as constipation, } \\
\text { numbness, myalgia, abdominal pain, } \\
\text { fatigue, tingling, weakness, irregular } \\
\text { heartbeat, muscle cramps, and } \\
\text { palpitation. }\end{array}$} \\
\hline & & Tachycardia & $5(45.4)$ & \\
\hline & & Constipation & $5(45.4)$ & \\
\hline & & Confusion & $4(36.4)$ & \\
\hline & & Irregular heart rate & $3(27.3)$ & \\
\hline & & Hypokalemia & $2(18.2)$ & \\
\hline & & Vomiting & $1(9.1)$ & \\
\hline & \multirow[t]{5}{*}{ High + Low (11) } & Fever & $5(45.4)$ & \\
\hline & & Confusion & $4(36.4)$ & \\
\hline & & Constipation & $3(27.3)$ & \\
\hline & & Hypokalemia & $3(27.3)$ & \\
\hline & & Tachycardia & $2(18.2)$ & \\
\hline
\end{tabular}


Table 7 Clinical relevance, dose considerations, and monitoring/management guidelines of top-10 pDDIs in patients with pneumonia (Continued)

\begin{tabular}{|c|c|c|c|c|}
\hline Interactions $^{a}$ & Dose categories ${ }^{a}$ & $\begin{array}{l}\text { Signs and symptoms and } \\
\text { Laboratory abnormalities }\end{array}$ & Patients: $\mathrm{n}\left(\%^{\mathrm{C}}\right)$ & Monitoring/management guidelines \\
\hline & & Irregular heart rate & $1(9.1)$ & \\
\hline & \multirow[t]{7}{*}{ Low + High (11) } & Fever & $7(63.6)$ & \\
\hline & & Tachycardia & $4(36.4)$ & \\
\hline & & Constipation & $3(27.3)$ & \\
\hline & & Hypokalemia & $3(27.3)$ & \\
\hline & & Irregular heart rate & $3(27.3)$ & \\
\hline & & Nausea & $2(18.2)$ & \\
\hline & & Confusion & $1(9.1)$ & \\
\hline & \multirow[t]{5}{*}{ Low + Low (6) } & Fever & $4(66.7)$ & \\
\hline & & Tachycardia & $4(66.7)$ & \\
\hline & & Hypokalemia & $3(50)$ & \\
\hline & & Irregular heart rate & $2(33.3)$ & \\
\hline & & Vomiting & $1(16.7)$ & \\
\hline \multirow{12}{*}{$\begin{array}{l}\text { Aspirin - } \\
\text { Clopidogrel (37) }\end{array}$} & \multirow[t]{2}{*}{ High + Low (2) } & Bradycardia & $1(50)$ & \multirow{12}{*}{$\begin{array}{l}\text { Monitor patients' platelets counts and } \\
\text { any sign of bleeding. If an adverse effect } \\
\text { is noted, the following options may be } \\
\text { considered: (a) Decrease the dose of } \\
\text { aspirin (b) GIT protection through } \\
\text { proton pump inhibitors and patient } \\
\text { should be educated about non- } \\
\text { prescribed use of analgesics. }\end{array}$} \\
\hline & & Hypotension & $1(50)$ & \\
\hline & \multirow[t]{10}{*}{ Low + Low (35) } & Hypotension & $14(40)$ & \\
\hline & & Tachycardia & $9(26)$ & \\
\hline & & Increased APTT & $9(26)$ & \\
\hline & & Drowsiness & $7(20)$ & \\
\hline & & Increased PT & $7(20)$ & \\
\hline & & Weakness & $6(17.1)$ & \\
\hline & & Increased INR & $5(14.3)$ & \\
\hline & & Decreased platelets & $4(11.4)$ & \\
\hline & & Palpitations & $1(2.9)$ & \\
\hline & & Bradycardia & $1(2.9)$ & \\
\hline \multirow{12}{*}{$\begin{array}{l}\text { Aspirin - Insulin } \\
\text { (33) }\end{array}$} & \multirow[t]{9}{*}{ Low + High (27) } & Tachycardia & $11(41)$ & \multirow{9}{*}{$\begin{array}{l}\text { Monitoring of patient's blood glucose } \\
\text { and clinical signs of hypoglycemia is } \\
\text { suggested. Adjust the dose of insulin if } \\
\text { necessary. }\end{array}$} \\
\hline & & Loss of consciousness & $7(26)$ & \\
\hline & & Drowsiness & $5(18.5)$ & \\
\hline & & Pale & $3(11.1)$ & \\
\hline & & Confusion & $2(7.4)$ & \\
\hline & & Decreased FBS & $2(7.4)$ & \\
\hline & & Irritability & $1(3.7)$ & \\
\hline & & Seizures & $1(3.7)$ & \\
\hline & & Palpitations & $1(3.7)$ & \\
\hline & \multirow[t]{2}{*}{ Low + Low (5) } & Pale & $1(20)$ & \\
\hline & & Tachycardia & $1(20)$ & \\
\hline & High + Low (1) & Confusion & $1(100)$ & \\
\hline \multirow{6}{*}{$\begin{array}{l}\text { Isoniazid - } \\
\text { Rifampin (33) }\end{array}$} & \multirow[t]{6}{*}{ Low + Low (27) } & Fever & $22(81.5)$ & \multirow{6}{*}{$\begin{array}{l}\text { Monitoring of hepatotoxicity (jaundice, } \\
\text { vomiting, fever, anorexia, and LFTs) is } \\
\text { advised. }\end{array}$} \\
\hline & & Anorexia & $12(44.4)$ & \\
\hline & & Increased ALP & $9(33.3)$ & \\
\hline & & Vomiting & $6(22.2)$ & \\
\hline & & Pale & $5(18.5)$ & \\
\hline & & Anemia & $3(11.1)$ & \\
\hline
\end{tabular}


Table 7 Clinical relevance, dose considerations, and monitoring/management guidelines of top-10 pDDls in patients with pneumonia (Continued)

\begin{tabular}{|c|c|c|c|c|}
\hline Interactions $^{a}$ & Dose categories ${ }^{a}$ & $\begin{array}{l}\text { Signs and symptoms and } \\
\text { Laboratory abnormalities }^{\mathrm{b}}\end{array}$ & Patients: $\mathrm{n}\left(\%^{\mathrm{C}}\right)$ & Monitoring/management guidelines \\
\hline & & Weight loss & $2(7.4)$ & \\
\hline & & Weakness & $2(7.4)$ & \\
\hline & & Increased ALT & $2(7.4)$ & \\
\hline & & Increased serum bilirubin & $2(7.4)$ & \\
\hline & & Epigastric pain & $1(3.7)$ & \\
\hline & & Hepatic encephalopathy & $1(3.7)$ & \\
\hline & & Tiredness & $1(3.7)$ & \\
\hline & High + High (6) & Fever & $6(100)$ & \\
\hline & & Increased ALP & $3(50)$ & \\
\hline & & Anorexia & $2(33.3)$ & \\
\hline & & Epigastric pain & $1(16.7)$ & \\
\hline & & Weight loss & $1(16.7)$ & \\
\hline & & Pale & $1(16.7)$ & \\
\hline & & Increased ALT & $1(16.7)$ & \\
\hline & & Increased serum bilirubin & $1(16.7)$ & \\
\hline \multirow{22}{*}{$\begin{array}{l}\text { Calcium } \\
\text { containing } \\
\text { products - } \\
\text { Ceftriaxone (33) }\end{array}$} & Low + Low (19) & Fever & $11(57.9)$ & \multirow{22}{*}{$\begin{array}{l}\text { Ceftriaxone should not be mixed or } \\
\text { administered concomitantly with } \\
\text { calcium-containing intravenous } \\
\text { preparations in the same intravenous } \\
\text { administration line. Monitor patient for } \\
\text { signs of nephrotoxicity or decreased } \\
\text { ceftriaxone effectiveness. }\end{array}$} \\
\hline & & Increased BUN & $10(52.6)$ & \\
\hline & & Cough & $9(47.4)$ & \\
\hline & & Increased serum bilirubin & $7(36.8)$ & \\
\hline & & Leukocytosis & $7(36.8)$ & \\
\hline & & Chest pain & $2(10.5)$ & \\
\hline & Low + High (7) & Cough & $4(57.1)$ & \\
\hline & & Fever & $3(42.8)$ & \\
\hline & & Increased BUN & $3(42.8)$ & \\
\hline & & Increased serum bilirubin & $3(42.8)$ & \\
\hline & & Leukocytosis & $2(28.6)$ & \\
\hline & & Chest pain & $1(14.3)$ & \\
\hline & High + Low (5) & Fever & $4(80)$ & \\
\hline & & Increased BUN & $2(40)$ & \\
\hline & & Increased serum bilirubin & $2(40)$ & \\
\hline & & Leukocytosis & $2(40)$ & \\
\hline & & Chest pain & $2(40)$ & \\
\hline & & Cough & $1(20)$ & \\
\hline & & Sepsis & $1(20)$ & \\
\hline & High + High (2) & Increased BUN & $2(100)$ & \\
\hline & & Increased serum bilirubin & $2(100)$ & \\
\hline & & Leukocytosis & $2(100)$ & \\
\hline \multirow{6}{*}{$\begin{array}{l}\text { Pyrazinamide - } \\
\text { Rifampin (32) }\end{array}$} & Low + Low (28) & Fever & $23(82.1)$ & \multirow{6}{*}{$\begin{array}{l}\text { Monitoring of LFTs during treatment is } \\
\text { recommended. }\end{array}$} \\
\hline & & Anorexia & $13(46.4)$ & \\
\hline & & Increased ALP & $10(35.7)$ & \\
\hline & & Vomiting & $6(21.4)$ & \\
\hline & & Pale & $5(17.8)$ & \\
\hline & & Anemia & $3(10.7)$ & \\
\hline
\end{tabular}


Table 7 Clinical relevance, dose considerations, and monitoring/management guidelines of top-10 pDDIs in patients with pneumonia (Continued)

\begin{tabular}{|c|c|c|c|c|}
\hline Interactions $^{a}$ & Dose categories $^{a}$ & $\begin{array}{l}\text { Signs and symptoms and } \\
\text { Laboratory abnormalities }\end{array}$ & Patients: $\mathrm{n}\left(\%{ }^{\mathrm{C}}\right)$ & Monitoring/management guidelines \\
\hline & & Increased serum bilirubin & $2(7.1)$ & \\
\hline & & Weakness & $2(7.1)$ & \\
\hline & & Weight loss & $2(7.1)$ & \\
\hline & & Increased ALT & $1(3.6)$ & \\
\hline & & Epigastric pain & $1(3.6)$ & \\
\hline & & Hepatic encephalopathy & $1(3.6)$ & \\
\hline & & Tiredness & $1(3.6)$ & \\
\hline & \multirow[t]{6}{*}{ High + High (4) } & Fever & $4(100)$ & \\
\hline & & Increased ALP & $2(50)$ & \\
\hline & & Anorexia & $1(25)$ & \\
\hline & & Epigastric pain & $1(25)$ & \\
\hline & & Increased ALT & $1(25)$ & \\
\hline & & Increased serum bilirubin & $1(25)$ & \\
\hline \multirow{15}{*}{$\begin{array}{l}\text { Aspirin - Ramipril } \\
\text { (28) }\end{array}$} & \multirow[t]{9}{*}{ Low + Low (21) } & Increased BUN & $18(85.7)$ & \\
\hline & & $\begin{array}{l}\text { Increased serum } \\
\text { creatinine }\end{array}$ & $12(57.1)$ & \\
\hline & & Hypertension & $9(42.8)$ & \\
\hline & & Tachycardia & $8(38.1)$ & \\
\hline & & Confused & $3(14.3)$ & \\
\hline & & Hypokalemia & $3(14.3)$ & \\
\hline & & Chest pain & $2(9.5)$ & \\
\hline & & Headache & $1(4.7)$ & \\
\hline & & Irregular heart rate & $1(4.7)$ & \\
\hline & \multirow[t]{6}{*}{ Low + High (7) } & Hypertension & $5(71.4)$ & $\begin{array}{l}\text { Monitor patients' blood pressure, } \\
\text { hemodynamic parameters, and renal } \\
\text { function. Incase of an adverse event, } \\
\text { consider the following: (a) replace ACE } \\
\text { inhibitors with angiotensin receptor } \\
\text { blockers (b) an alternative non-aspirin } \\
\text { antiplatelet agent (c) aspirin dosage less } \\
\text { than } 100 \mathrm{mg} \text { per day. }\end{array}$ \\
\hline & & Increased BUN & $3(42.8)$ & \\
\hline & & $\begin{array}{l}\text { Increased serum } \\
\text { creatinine }\end{array}$ & $3(42.8)$ & \\
\hline & & Tachycardia & $2(28.6)$ & \\
\hline & & Chest pain & $1(14.3)$ & \\
\hline & & Hyperkalemia & $1(14.3)$ & \\
\hline \multirow{13}{*}{$\begin{array}{l}\text { Albuterol - } \\
\text { Furosemide (28) }\end{array}$} & \multirow[t]{7}{*}{ High + High (9) } & Tachycardia & $4(44.4)$ & \multirow{13}{*}{$\begin{array}{l}\text { Potassium balance and cardiovascular } \\
\text { status should be monitored, especially if } \\
\text { the beta-2 agonist is administered by } \\
\text { nebulizer or systemically. Patients should } \\
\text { be advised to inform their physician if } \\
\text { they experience potential signs/ } \\
\text { symptoms of hypokalemia such as } \\
\text { constipation, numbness, myalgia, } \\
\text { abdominal pain, fatigue, tingling, } \\
\text { weakness, irregular heartbeat, muscle } \\
\text { cramps, and palpitation. }\end{array}$} \\
\hline & & Constipation & $4(44.4)$ & \\
\hline & & Fever & $3(33.3)$ & \\
\hline & & Hypokalemia & $3(33.3)$ & \\
\hline & & Confusion & $2(22.2)$ & \\
\hline & & Vomiting & $1(11.1)$ & \\
\hline & & Dehydration & $1(11.1)$ & \\
\hline & \multirow[t]{6}{*}{ High + Low (17) } & Constipation & $4(23.5)$ & \\
\hline & & Tachycardia & $4(23.5)$ & \\
\hline & & Hypokalemia & $4(23.5)$ & \\
\hline & & Confusion & $3(17.6)$ & \\
\hline & & Vomiting & $2(11.7)$ & \\
\hline & & Fatigue & $2(11.7)$ & \\
\hline
\end{tabular}


Table 7 Clinical relevance, dose considerations, and monitoring/management guidelines of top-10 pDDls in patients with pneumonia (Continued)

\begin{tabular}{|c|c|c|c|c|}
\hline Interactions $^{a}$ & Dose categories ${ }^{a}$ & $\begin{array}{l}\text { Signs and symptoms and } \\
\text { Laboratory abnormalities }\end{array}$ & Patients: $\mathrm{n}\left(\%^{\mathrm{C}}\right)$ & Monitoring/management guidelines \\
\hline & & Weakness & $2(11.7)$ & \\
\hline & & Fever & $1(5.9)$ & \\
\hline & Low + High (1) & Constipation & $1(100)$ & \\
\hline & Low + Low (1) & Constipation & $1(100)$ & \\
\hline \multirow{16}{*}{$\begin{array}{l}\text { Aspirin - } \\
\text { Bisoprolol (23) }\end{array}$} & \multirow[t]{7}{*}{ Low + Low (14) } & Hypertension & $7(50)$ & \multirow{15}{*}{$\begin{array}{l}\text { Patients' blood pressure and } \\
\text { hemodynamic parameters should be } \\
\text { monitored. }\end{array}$} \\
\hline & & Tachycardia & $4(28.5)$ & \\
\hline & & Chest pain & $3(21.4)$ & \\
\hline & & Irregular heart rate & $2(14.3)$ & \\
\hline & & Headache & $2(14.3)$ & \\
\hline & & Restless & $1(7.1)$ & \\
\hline & & Drowsiness & $1(7.1)$ & \\
\hline & \multirow[t]{4}{*}{ Low + High (7) } & Hypertension & $6(85.7)$ & \\
\hline & & Tachycardia & $6(85.7)$ & \\
\hline & & Chest pain & $3(42.8)$ & \\
\hline & & Irregular heart rate & $2(28.6)$ & \\
\hline & \multirow[t]{4}{*}{ High + High (1) } & Irregular heart rate & $1(100)$ & \\
\hline & & Headache & $1(100)$ & \\
\hline & & Hypertension & $1(100)$ & \\
\hline & & Tachycardia & $1(100)$ & \\
\hline & High + Low (1) & - & - & \\
\hline
\end{tabular}

ALT Alanine Aminotransferase, ACE Angiotensin Converting Enzyme, ALP Alkaline Phosphatase, APTT Activated Partial Thromboplastin Time, BUN Blood Urea Nitrogen, FBS Fasting Blood Sugar, GIT Gastrointestinal Tract, HbA1c Glycated hemoglobin (A1c), INR International Normalized Ratio, LFTs Liver Function Tests, PT Prothrombin Time, RBS Random Blood Sugar

${ }^{\mathrm{a}}$ Frequencies were given in round brackets

${ }^{b}$ Adverse outcomes were defined as follows, increased blood urea nitrogen (BUN): BUN $\leq 20 \mathrm{mg} / \mathrm{dL}$; increased serum creatinine: serum creatinine $>1.06 \mathrm{mg} / \mathrm{dL}$; hypernatremia: serum sodium > $145 \mathrm{mmol} / \mathrm{L}$; hyponatremia: serum sodium < $135 \mathrm{mmol} / \mathrm{L}$; hyperkalemia: serum potassium $>5.5 \mathrm{mmol} / \mathrm{L}$; hypokalemia: serum potassium < $3.5 \mathrm{mmol} / \mathrm{L}$; hyperchloremia: serum chloride $>105 \mathrm{mmol} / \mathrm{L}$; hypertension: systolic blood pressure $(\mathrm{BP})>130 \mathrm{mmHg}$ and/or diastolic $\mathrm{BP}>90 \mathrm{mmHg}$; hypotension: systolic BP $<80 \mathrm{mmHg}$ and/or diastolic $\mathrm{BP}<50 \mathrm{mmHg}$; tachycardia: heart rate $>100$ beats $/ \mathrm{min}$; bradycardia: heart rate $<70$ beats $/ \mathrm{min}$; increased activated partial thromboplastin time (APTT): APTT > $35.5 \mathrm{~s}$; increased prothrombin time (PT): PT > $15.5 \mathrm{~s}$; increased international normalized ratio (INR): INR > 1.2; decreased platelets: platelets count $<150,000 / \mu \mathrm{L}$; hypoglycemia: random blood sugar $<80 \mathrm{mg} / \mathrm{dL}$ or fasting blood sugar $<70 \mathrm{mg} / \mathrm{dL}$; increased alkaline phosphatase: > $126 \mathrm{U} / \mathrm{L}$; increased serum bilirubin: $>1 \mathrm{mg} / \mathrm{dL}$; increased alanine aminotransferase: $>59 \mathrm{U} / \mathrm{L}$ (male), $>36 \mathrm{U} / \mathrm{L}$ (female); leukocytosis: total leukocyte count $>11,000 / \mu \mathrm{L}$

cPercentages were calculated based on dose categories

of sudden death due to cardiac causes, among patients who were treated with erythromycin and CYP3A inhibitors, concurrently [40].

\section{Conclusions}

PDDIs are highly prevalent in patients with pneumonia. Computerized drug interactions screening programs will help in identification, prevention, and minimization of pDDIs in pneumonia patients. Most frequent and clinically important pDDIs need particular attention. Polypharmacy and tuberculosis increase the risk of pDDIs. Identifying patients more at risk to pDDIs and careful monitoring of pertinent signs/symptoms and laboratory investigations are important measures to reduce pDDIs and their related adverse consequences.

\section{Abbreviations}

ACE: Angiotensin converting enzyme; ADRs: Adverse drug reactions; ALP: Alkaline phosphatase; ALT: Alanine aminotransferase; APTT: Activated partial thromboplastin time; ATD: Alternate day; BD: Twice a day; BP: Blood pressure; BUN: Blood urea nitrogen; Cl: Confidence interval; DDls: Drug-drug interactions; FBS: Fasting blood sugar; GIT: Gastrointestinal tract; HbA1c: Glycated hemoglobin (A1c); HMC: Hayatabad medical complex; INR: International normalized ratio; IQR: Interquartile range; KTH: Khyber teaching hospital; LFTs: Liver function tests; OD: Once a day; OR: Odds ratios; pDDIs: potential DDIs; PT: Prothrombin time; QID: Four times a day; RBS: Random blood sugar; TDS: Three times a day

\section{Acknowledgements}

Authors are very grateful for the cooperation of staff and administration of the hospitals.

\section{Authors' contributions}

All authors contributed substantially to the work presented in this paper, read and approved the final manuscript. SN designed all the work under the supervision of Ml, collected, analyzed and interpreted data, did DDls screening, drafted the manuscript. Ml designed the research, contributed 
substantially with data analysis, results interpretations and manuscript editing and approval. ZA collected the patients' data and did DDls screening.

\section{Funding}

No funding has been taken for this study.

\section{Availability of data and materials}

The datasets used and/or analyzed during the current study are available from the corresponding author on reasonable request.

\section{Ethics approval and consent to participate}

Ethics approval was granted by the Institutional Research and Ethics Board (IREB) of Postgraduate Medical Institute, Peshawar. Informed consent from the patients was not applicable. As our study contains the data obtained from the hospital record.

\section{Consent for publication}

Not applicable.

\section{Competing interests}

The authors declare that they have no competing interests.

Received: 19 September 2018 Accepted: 18 July 2019

Published online: 26 July 2019

\section{References}

1. Zar HJ, Madhi SA, Aston SJ, Gordon SB. Pneumonia in low and middle income countries: progress and challenges. Thorax. 2013;68:1052-6.

2. World Health Organization. Pneumonia. 2016. http://www.who.int/ mediacentre/factsheets/fs331/en/. Accessed 2 Jan 2018.

3. Nair H, Simoes EA, Rudan I, Gessner BD, Azziz-Baumgartner E, Zhang JS, et al. Global and regional burden of hospital admissions for severe acute lower respiratory infections in young children in 2010: a systematic analysis. Lancet. 2013;381:1380-90.

4. Wesemann T, Nullmann H, Pflug MA, Heppner HJ, Pientka L, Thiem U. Pneumonia severity, comorbidity and 1-year mortality in predominantly older adults with community-acquired pneumonia: a cohort study. BMC Infect Dis. 2015;15:2.

5. Al-Khaldi YM, Diab MMAA, Al-Gelban KS, Al-Asmari AS, Al-Amin S, AlShahrani MS. Prescribing patterns for acute respiratory infections in primary health care, Aseer region, Saudi Arabia. J Family Community Med. 2005;12:121-6.

6. Gamble JM, Hall JJ, Marrie TJ, Sadowski CA, Majumdar SR, Eurich DT. Medication transitions and polypharmacy in older adults following acute care. Ther Clin Risk Manag. 2014;10:189-96.

7. Zwart-van Rijkom JE, Uijtendaal EV, ten-Berg MJ, van-Solinge WW, Egberts $A C$. Frequency and nature of drug-drug interactions in a Dutch university hospital. Br J Clin Pharmacol. 2009:68:187-93.

8. Juurlink DN, Mamdani M, Kopp A, Laupacis A, Redelmeier DA. Drug-drug interactions among elderly patients hospitalized for drug toxicity. JAMA. 2003;289:1652-8.

9. Dechanont S, Maphanta S, Butthum B, Kongkaew C. Hospital admissions/ visits associated with drug-drug interactions: a systematic review and metaanalysis. Pharmacoepidemiol Drug Saf. 2014;23:489-97.

10. Kohler G, Bode-Boger S, Busse R, Hoopmann M, Welte T, Boger R. Drug-drug interactions in medical patients: effects of in-hospital treatment and relation to multiple drug use. Int J Clin Pharmacol Ther. 2000;38:504-13.

11. Vonbach P, Dubied A, Beer JH, Krahenbuhl S. Recognition and management of potential drug-drug interactions in patients on internal medicine wards. Eur J Clin Pharmacol. 2007;63:1075-83.

12. van-Leeuwen RW, Brundel DH, Neef C, van-Gelder T, Mathijssen RH, Burger $\mathrm{DM}$, et al. Prevalence of potential drug-drug interactions in cancer patients treated with oral anticancer drugs. Br J Cancer. 2013;108:1071-8.

13. Hahn M, Reiff J, Hiemke C, Braus DF. Drug-drug-interactions in psychiatry. Psychiatr Prax. 2013;40:154-8

14. Murtaza G, Khan MY, Azhar S, Khan SA, Khan TM. Assessment of potential drug-drug interactions and its associated factors in the hospitalized cardiac patients. Saudi Pharm J. 2016:24:220-5.

15. Ismail M, Iqbal Z, Khattak MB, Khan Ml, Arsalan H, Javaid A, et al. Potential drug-drug interactions in internal medicine wards in hospital setting in Pakistan. Int J Clin Pharm. 2013;35:455-62.
16. Daniel WW, Cross CL. Biostatistics: A foundation for analysis in the health sciences. 10th ed. Wiley: USA; 2013.

17. Micromedex Drug-Reax ${ }^{\circledast}$, Greenwood Village, CO: Truven Health Analytics. https://www.micromedexsolutions.com/micromedex2/librarian/ssl/true. Accessed 20 Oct 2017.

18. Noor S, Ismail M, Haider I, Khadim F. Drug-drug interactions in hepatitis patients: do these interactions matter in clinical perspectives? Ann Hepatol. 2018;17:1001-11.

19. Vanham D, Spinewine A, Hantson P, Wittebole X, Wouters D, Sneyers B. Drug-drug interactions in the intensive care unit: do they really matter? J Crit Care. 2017;38:97-103.

20. Teka F, Teklay G, Ayalew E, Teshome T. Potential drug-drug interactions among elderly patients admitted to medical ward of Ayder referral hospital, Northern Ethiopia: a cross sectional study. BMC Res Notes. 2016;9:431.

21. Baxter K, editor. Stockley's drug interactions. 9th ed. London, Chicago: Pharmaceutical Press; 2010

22. Santos WM, Secoli SR, Padoin SM. Potential drug interactions in patients given antiretroviral therapy. Rev Lat Am Enfermagem. 2016;24:e2832.

23. Franz CC, Egger S, Born C, Ratz-Bravo AE, Krahenbuhl S. Potential drug-drug interactions and adverse drug reactions in patients with liver cirrhosis. Eur J Clin Pharmacol. 2012:68:179-88.

24. Subramanian A, Adhimoolam M, Kannan S. Study of drug-drug interactions among the hypertensive patients in a tertiary care teaching hospital. Perspect Clin Res. 2018;9:9-14.

25. Masukawa MY, Veríssimo GB, Richtzenhain MH, Linardi A. Drug interactions in children with respiratory diseases in the pediatric unit of a teaching hospital in Brazil. Revista Cubana de Pediatria. 2016;88:166-81.

26. Roblek T, Trobec K, Laina M. Drug-drug interactions in hospitalized patients with chronic obstructive pulmonary disease. Eur Respir J. 2012:40:P2159

27. Raddad AR, Rashed AO, Bsharat A, Abu-Ghazaleh D, Yasin E, Shehab O. Evaluation of potential drug-drug interactions among Palestinian hemodialysis patients. BMC Nephrol. 2016;17:96-201.

28. Kondili LA, Gaeta GB, leluzzi D, Zignego AL, Monti M, Gori A, et al. Real-life data on potential drug-drug interactions in patients with chronic hepatitis $C$ viral infection undergoing antiviral therapy with interferon-free DAAs in the PITER cohort study. PLOS One. 2017;12:e0172159.

29. Moura C, Prado NM, Belo NO, Acurcio FA. Evaluation of drug-drug interaction screening software combined with pharmacist intervention. Int J Clin Pharm. 2012;34:547-52.

30. Langness JA, Nguyen M, Wieland A, Everson GT, Kiser JJ. Optimizing hepatitis $C$ virus treatment through pharmacist interventions: identification and management of drug-drug interactions. World J Gastroenterol. 2017:23:1618-26.

31. van-Roon EN, Flikweert S, le-Comte M, Langendijk PN, Kwee-Zuiderwijk WJ, Smits $P$, et al. Clinical relevance of drug-drug interactions: a structured assessment procedure. Drug Saf. 2005;28:1131-9.

32. Geerts AF, De-Koning FH, De-Smet PA, Van-Solinge WW, Egberts TC Laboratory tests in the clinical risk management of potential drug-drug interactions: a cross-sectional study using drug-dispensing data from 100 Dutch community pharmacies. Drug Saf. 2009;32:1189-97.

33. Gnjidic D, Hilmer SN, Blyth FM, Naganathan V, Waite L, Seibel MJ, et al. Polypharmacy cutoff and outcomes: five or more medicines were used to identify community-dwelling older men at risk of different adverse outcomes. J Clin Epidemiol. 2012;65:989-95.

34. Masnoon N, Shakib S, Kalisch-Ellett L, Caughey GE. What is polypharmacy? A systematic review of definitions. BMC Geriatr. 2017;17:230.

35. Ibanez A, Alcala M, Garcia J, Puche E. Drug-drug interactions in patients from an internal medicine service. Farm Hosp. 2008;32:293-7.

36. Ismail M, Aziz S, Noor S, Haider I, Shams F, Haq I, et al. Potential drug-drug interactions in pediatric patients admitted to intensive care unit of Khyber teaching hospital, Peshawar, Pakistan: a cross-sectional study. J Crit Care. 2017:40:243-50

37. Stoll P, Kopittke L. Potential drug-drug interactions in hospitalized patients undergoing systemic chemotherapy: a prospective cohort study. Int J Clin Pharm. 2015:37:475-84.

38. Yew WW. Clinically significant interactions with drugs used in the treatment of tuberculosis. Drug Saf. 2002;25:111-33.

39. Egger SS, Drewe J, Schlienger RG. Potential drug-drug interactions in the medication of medical patients at hospital discharge. Eur J Clin Pharmacol. 2003;58:773-8. 
40. Ray WA, Murray KT, Meredith S, Narasimhulu SS, Hall K, Stein CM. Oral erythromycin and the risk of sudden death from cardiac causes. New Eng J Med. 2004:351:1089-96.

\section{Publisher's Note}

Springer Nature remains neutral with regard to jurisdictional claims in published maps and institutional affiliations.

Ready to submit your research? Choose BMC and benefit from:

- fast, convenient online submission

- thorough peer review by experienced researchers in your field

- rapid publication on acceptance

- support for research data, including large and complex data types

- gold Open Access which fosters wider collaboration and increased citations

- maximum visibility for your research: over $100 \mathrm{M}$ website views per year

At $\mathrm{BMC}$, research is always in progress. 